\title{
Growth and Instability of Onion Production in Maharashtra, India
} Immanuelraj TK, Dastagiri MB* and Sajesh VK

National Centre for Agricultural Economics and Policy Research, New Delhi, India

\begin{abstract}
This study mainly focused on Maharashtra's onion growth and instability. Erratic weather, volatile market price and lack of adequate storage and market infrastructure caused instability in production through preventing the farmers in taking the optimal decision on allocation of area and raising farm productivity. Study categorized period as follows; Period I: $1980-81$ to 1989-90, Period II: $1990-91$ to $1999-00$ and Period III: 2000-01 to $2010-11$ and revealed that onion production in Maharashtra is mainly driven by acreage allocation. But in the long-run increasing area under onion may not be feasible without reducing the area of other important crops. Hence, solution lies in by bridging the yield gap or increasing the yield potential. The major reason for the instability of onion production after period II was mainly due to area instability and partly due to yield instability.
\end{abstract}

Keywords: Onion; Production; Growth and instability; Maharashtra; India

\section{Introduction}

Onion is an important fresh vegetable consumed all over the world. India ranks first in acreage in the world covering about 480 thousand ha (21 per cent of the world area) and second in production after China, with over 15 million tons [1]. According to NSSO data, onion consumption has increased in both rural and urban areas by at least 100 and 150 gram respectively per month from 1993-94 to 2004-05.Further, this demand is likely to rise with increase of domestic population, per capita income, increasing taste consciousness and health awareness of the consumer [2]. Also, there is steady rise in export since the period of liberalization. Export competitiveness of onion is also found to be very high $[3,4]$.

In India, onion is cultivated mainly in three different seasons' viz., rainy kharif (20 per cent), late kharif ( 20 per cent) and rabi (60 per cent).Sowing of rainy kharif takes place during February-April in Southern India while in Maharashtra and other parts takes place during May-June. And so, late kharif is in August-September and Rabi is in October-November [5-7]. Erratic weather and volatile market price is the major factors causing fluctuation in production which result in excess supply or demand. This in turn leads to instability in production. The implication of instability is, on the one hand, price rise upsets consumers and contributes to inflationary pressures on economy and, on the other hand, a price fall diminishes the farm income thereby increases the poverty in rural areas [8]. Production and price instability lead to capital rationing and less than optimal resource allocation in agriculture [9]. Instability in agriculture may adversely affect growth in production, investment, employment, consumption, and income distribution, which may impede the economic development and growth of the country $[10,11]$.

Onion is produced in the states of Maharashtra, Karnataka, Madhya Pradesh, Rajasthan, Gujarat, Andhra Pradesh and Bihar which together constitute around 70 percent of the area under onion. Maharashtra Is reckoned as the leading state accounting for more than 30 per cent area with an average yield of 14.2 t/ha during TE 2011-12. As Maharashtra is major state contributes to the total production (33 per cent) and export (80-85 per cent) of India [12], this study focused on Maharashtra. This study attempted to examine the growth and instability of onion production in Maharashtra over the years with the following objectives (i) To study the compound annual growth rates in area, production and productivity (ii) To assess the components of change in production; and (iii) To examine the extent of instability in onion.

\section{Materials and Methods}

The current study made use of secondary time series data on area, production and productivity of onion from 1980-81 to 2010-11, that was collected from Directorate of Economics and Statistics [13], Government of India (GOI). The entire study period is categorized as follows; $1980-81$ to $1989-90$ (Period I), $1990-91$ to $1999-00$ (Period II), 2000-01 to 2010-11(Period III). The methodology used for this analysis is described as below. The compound growth rate was calculated by fitting exponential function to the area, production and yield.

\section{Components of Change}

Average production for entire time period, $\mathrm{E}(\mathrm{Q})$

$$
\begin{aligned}
& E(Q)=\mu_{A} \mu_{Y}+\operatorname{Cov}(A, Y) \\
& \mu_{\mathrm{A}}=\text { mean area } \\
& \mu_{\mathrm{Y}}=\text { mean yields } \\
& \operatorname{Cov}_{(\mathrm{A}, \mathrm{Y})}=\text { Covariance of area and yield }
\end{aligned}
$$

Average production for each time period

$$
\begin{aligned}
& E\left(Q_{1}\right)=\mu_{A 1} \mu_{Y 1}+\operatorname{Cov}\left(A_{1}, Y_{1}\right) \\
& E\left(Q_{2}\right)=\mu_{A 2} \mu_{Y 2}+\operatorname{Cov}\left(A_{2}, Y_{2}\right)
\end{aligned}
$$

Change in average production has four sources of changes:

$$
\Delta E(Q)=\mu_{A 1} \Delta \mu_{Y}+\mu_{Y 1} \Delta \mu_{A}+\Delta \mu_{A} \Delta \mu_{Y}+\Delta \operatorname{Cov}(A, Y)
$$

Where

*Corresponding author: Dastagiri MB, Principal Scientist, National Centre for Agricultural Economics and Policy Research, New Delhi, India; Tel: 09810619788; E-mail: dgiri_mb@yahoo.co.in

Received November 16, 2013; Accepted January 27, 2014; Published February 03, 2014

Citation: Immanuelraj TK, Dastagiri MB, Sajesh VK (2014) Growth and Instability of Onion Production in Maharashtra, India. J Glob Econ 2: 107. doi:10.4172/23754389.1000107

Copyright: () 2014 Immanuelraj TK, et al. This is an open-access article distributed under the terms of the Creative Commons Attribution License, which permits unrestricted use, distribution, and reproduction in any medium, provided the original author and source are credited. 


$\begin{array}{lll}\mu_{A 1} \Delta \mu_{Y} & = & \text { change in mean area } \\ \mu_{Y 1} \Delta \mu_{A} & = & \text { change in mean yield } \\ \Delta \mu_{A} \Delta \mu_{Y} & = & \text { interaction between changes } \\ \text { mean yield and mean area } & & \end{array}$

$\Delta \operatorname{Cov}(A, Y)=\quad$ changes in variability in area and yield

Change in all the sources of production are presented as ratios to the total production.

\section{Instability}

The data on yield and area of onion in Maharashtra for the time period were de-trended using a linear regression of the following form

$$
Z_{t}=a+b t+e_{t}
$$

Where

$\mathrm{Z}_{\mathrm{t}}=$ dependent variable (area or yield),

$\mathrm{a}=$ the intercept,

$\mathrm{b}=$ the parameter to be estimated,

$\mathrm{t}=$ time in years and

$e_{t}=$ the residual with mean zero and variance

The residuals were centered on mean area and mean yield.

$$
Z_{t}=e_{t}+\bar{Z}
$$

De-trended production $=$ de-trended area ${ }^{*}$ de-trended yield

The coefficient of variation $(\mathrm{CV})$, a standardized measure of instability,

$$
\mathrm{CV}=(\sigma / \overline{\mathrm{X}})^{*} 100
$$

Where, $\sigma=$ Standard deviation

$$
\bar{X}=\text { Mean }
$$

The sources of instability were quantified by decomposing the variance of production into the various sources (i.e. area variance, yield variance, and area-yield covariance). The production variance $\mathrm{V}(\mathrm{Q})$, where $\mathrm{Q}=\mathrm{AY}$, was estimated using the following formula from [14].

$$
\begin{aligned}
\operatorname{var}[A Y] & =\mu_{Y}^{2} \operatorname{var}[A]+\mu_{A}^{2} \operatorname{var}[Y]+2 \mu_{A} \mu_{Y} \operatorname{cov}[A, Y]-(\operatorname{cov}[A, Y])^{2} \\
& +E\left[\left(A-\mu_{A}\right)^{2}\left(Y-\mu_{Y}\right)^{2}\right]+2 \mu_{Y} E\left[\left(A-\mu_{A}\right)^{2}\left(Y-\mu_{Y}\right)\right] \\
& \left.+2 \mu_{A} E\left[A-\mu_{A}\right)\left(Y-\mu_{Y}\right)^{2}\right]
\end{aligned}
$$

Where $\mu \mathrm{A}$ and $\mu \mathrm{Y}$ are the mean area and mean yield and Var [A] and Var $[\mathrm{Y}]$ are the variance of area and yield, respectively. Cov $(\mathrm{A}, \mathrm{Y})$ is the area-yield covariance and $\operatorname{cov}(\mathrm{A}, \mathrm{Y})^{2}$ is the higher order covariance between area and yield.

\section{Granger Causality}

Causality test can be conducted to know the causal interaction between acreage (A) and price (P-Farm Harvest Price). The most commonly used causality test is Granger Causality. Following [15] the causal relationship between area (A) and Farm Harvest Price $(\mathrm{P})$ can be formally expressed as

${ }^{1}$ Null hypothesis is no Granger Causality that one time series is useful in predicting another

$$
\begin{aligned}
& A_{t}=\sum_{i=1}^{l} \alpha_{A i} A_{t-i}+\sum_{i=1}^{l} \beta_{A i} P_{t-i}+\varepsilon_{A t} \\
& P_{t}=\sum_{i=1}^{l} \alpha_{P i} A_{t-i}+\sum^{l} \beta_{P i} P_{t-i}+\varepsilon_{P t}
\end{aligned}
$$

Where, $l$ represents the ${ }^{i=1}$ maximum number of lag used in the model. However, maximum lag cannot be more than one year in the onion as it is a seasonal crop. The null hypothesis ${ }^{1}\left(\mathrm{H}_{0}\right)$ is tested by $\mathrm{F}$ statistics.

\section{Results and Discussion}

\section{Annual compound growth rate of onion}

Results of period wise compound annual growth rate of onion Table 1 reveals that area, production and yield have improved consistently over the periods. Increase in the area allocation that ranged from (1 to 10 per cent) was the main reason of production rather than any technological breakthrough, as indicated by the growth rate of land productivity, which was often less than two per cent or negative.

These show that there is good incentive in continuing and expanding onion acreage than other crops.

\section{Decomposition analysis of onion production}

Total changes in mean production of onion, as depicted in the below Table 2 , is increasing at increasing rate $(160<172$ percent $)$ in subsequent periods to the previous periods. The fact established in the Table 1 growth rate analysis was that area was the main contributor to the increase in production, which can be further confirmed through this decomposition analysis. At least 90 per cent of production hailed from change in mean area while contribution of yield was less than 5 per cent. The significance of this fact reminds that the excess demand for consumption and export cannot be met only by increasing area. Increase in area perhaps not possible without trade-off between other important food, fiber and horticultural crops. Hence, current low yield can't be further raised without exploiting the yield potential is inevitable in near future.

Moreover, there exist a wide yield gap between India and other developed countries as well as current yield and potential yield. In comparison to average onion yield of 15-16 MT in India, Korean

\begin{tabular}{|l|c|c|c|}
\hline Periods & Area (\%) & Production (\%) & Productivity (\%) \\
\hline Period I & 0.95 & -0.39 & -1.33 \\
\hline Period II & 5.4 & 1.97 & -3.25 \\
\hline Period III & 9.61 & 11.9 & 2.08 \\
\hline
\end{tabular}

Table 1: Annual Compound Growth Rate of Area, Production and Productivity of Onion.

\begin{tabular}{|l|l|l|l|l|l|l|}
\hline & $\begin{array}{l}\text { Change } \\
\text { in } \\
\text { mean } \\
\text { area } \\
(\%)\end{array}$ & $\begin{array}{l}\text { Change } \\
\text { in } \\
\text { mean } \\
\text { yield } \\
(\%)\end{array}$ & $\begin{array}{l}\text { Interaction } \\
\text { between } \\
\text { change } \\
\text { in mean } \\
\text { yield and } \\
\text { mean area } \\
\text { (\%) }\end{array}$ & $\begin{array}{l}\text { Change in } \\
\text { area - yield } \\
\text { covariance } \\
(\%)\end{array}$ & $\begin{array}{l}\text { Total } \\
\text { change } \\
\text { in mean } \\
\text { production }\end{array}$ & \\
\hline & & & & $\begin{array}{l}\text { Quantity } \\
\text { “000" T }\end{array}$ & (\%) \\
\hline $\begin{array}{c}\text { Period I } \\
\text { to II }\end{array}$ & 102.85 & -2.05 & -1.31 & 0.51 & 428.9 & 160.08 \\
\hline $\begin{array}{c}\text { Period II } \\
\text { to III }\end{array}$ & 91.31 & 4.71 & 4.02 & -0.04 & 820.44 & 171.79 \\
\hline
\end{tabular}

Table 2: Components of Total Change in Area, Production and Yield of Onion. 
Citation: Immanuelraj TK, Dastagiri MB, Sajesh VK (2014) Growth and Instability of Onion Production in Maharashtra, India. J Glob Econ 2: 107. doi:10.4172/2375-4389.1000107

Page 3 of 4

republic is around $66.67 \mathrm{MT} / \mathrm{ha}$, USA with 56.56 , Spain 53.53 and Netherland 48.81 MT, china 22.21 MT [16]. Hence, there is a huge scope to increase yields in India in general and particular to Maharashtra.

NHRDF [5,6] attributed several reasons for sluggish growth in yield and production of onion in India. They are non-availability of high yielding quality seeds for all the seasons, sub-optimal standards of cultivation adopted by farmers, inadequate access to cost effective storage facilities. In addition to that susceptibility to pests and diseases, lack of post-harvest facilities and policy support has contributed to some extent.

The contribution of interaction between change in mean yield and mean area and change in area and yield covariance was also less than 5 per cent, which was insignificant in its contribution to production.

Coefficient of variation in the de-trended onion data series disclose that, production stability was disturbed by both area and yield instability. Area stability has deteriorated from 3.55 percent in period I to 14 percent in period III. A notable thing in period I and period II, yield instability was larger in relation to area instability. It implies, before 2000, weather factors played major role. But, the trend has changed in the recent years. As indicated in the Table 3 during period III, area instability played major role (14 percent) than the yield instability (9.11 percent). These finding can be further confirmed by the decomposition of production variance.

\section{Decomposition of variance}

All through the years from 1980 to 2000 (Period I and II), yield variance was around 68 percent and area variance was ranging from 13.6 to 19.6 percent. However in the later period, area variance have risen to 62 percent and yield variance diminished to 26 percent. The major part of production instability (68 percent).As indicated in the Table 4 during period I and II are due to yield instability which is mainly due to poor weather, infestation of pest and disease. Area instability was almost 20 percent. However, in the period III, production instability was due to area instability. This may be ascribed to the increasing area under onion, volatility in the market price and erratic weather. The risk associated with volatility of market price can be reduced by providing timely and easy accessibility to market information to the farmers regarding farm gate and Mandy level prices, grading information, prediction of expected production during the three seasons, expected prices around the month at different markets including domestic and foreign markets, storage cost and availability of storage facility and predicted returns to storage. Extending the weather based crop insurance scheme to onion is one way to protect the small farmers against weather related issue on onion.

\begin{tabular}{|c|c|c|c|}
\hline Periods & Area (\%) & Production (\%) & Productivity (\%) \\
\hline Period I & 3.55 & 9.62 & 7.96 \\
\hline Period II & 9.87 & 22.26 & 18.42 \\
\hline Period III & 14.02 & 17.79 & 9.11 \\
\hline
\end{tabular}

Table 3: Instability in Area, Production and Productivity of Onion.

\begin{tabular}{|l|c|c|c|c|}
\hline Periods & $\begin{array}{c}\text { Area } \\
\text { variance (\%) }\end{array}$ & $\begin{array}{c}\text { Yield } \\
\text { variance (\%) }\end{array}$ & $\begin{array}{c}\text { Area-yield } \\
\text { covariance (\%) }\end{array}$ & $\begin{array}{c}\text { Higher order } \\
\text { interaction } \\
\text { between area } \\
\text { and yield (\%) }\end{array}$ \\
\hline Period I & 13.6 & 68.5 & 19.07 & -1.17 \\
\hline Period II & 19.6 & 68.32 & 10.99 & 1.09 \\
\hline Period III & 62.32 & 26.34 & 7.45 & 3.89 \\
\hline
\end{tabular}

Table 4: Sources of Change in Variance of Onion Production.

\begin{tabular}{|c|c|c|c|}
\hline Causality & F-Statistics & P Value & Direction \\
\hline area $\rightarrow$ price & 11.78 & 0.002 & Bidirectional at $10 \%$ Los and \\
\hline price $\rightarrow$ area & 3.67 & 0.067 & Unidirectional at $1 \%$ and $5 \%$ Los \\
\hline
\end{tabular}

To examine the necessity of increasing the yield of onion, existing direction of relationship between the price and acreage was studied and is presented in Table 5 .

The result of Granger Causality imply that at $1 \%$ or $5 \%$ Level of Significance (LoS), area Granger causes the price while price doesn't granger causes the area. It is a unidirectional relationship. However, at $10 \%$ LoS, the relationship is bidirectional.

Unlike food grain, as onion is being cultivated three seasons in a year, mainly for commercial purpose, not for home consumption (subsistence) purpose, caution should be exercised while interpreting the result. If market price is not incentive enough, farmer will not produce onion as it causes him earn less net income. Hence, price is the important variable considered by the farmer to decide on the acreage allocation. On the other hand, as Indian households demand significant portion of onion for culinary purpose on daily basis, deficit supply (less acreage and less production) will lead to inflation as witnessed by the bitter experience in the past. In other words, given the demand for onion is inelastic nature, over or under supply of onion will lead to glut or shortage respectively. That, in turn will be reflected in the price, followed by acreage. Hence, the expected direction of relationship between price and acreage is theoretically to be bidirectional.

The empirical result of unidirectional relationship between area and price at $1 \%$ and $5 \% \operatorname{LoS}$ may be due annual data used in the study. Considering theoretical reason, it is safe to assume, there exist bidirectional relationship between the variable of interest. The implication of the finding is, if productivity per hectare is not increased, to meet the growing demand due to growth of population, per capita income and other factors, acreage under onion has to be scaled up. If acreage is not allowed to increase (due to policy, weather factors), sensitive onion price will rise exorbitantly, or export has to restricted or import has to be resorted which will entail loss of foreign exchange.

\section{Conclusion}

Although, productivity of onion has improved from last decade, still onion production is mainly driven by acreage allocation. As onion is irrigated crop and Maharashtra is endowed with relatively less irrigation potential, increasing production through scaling up area may not be feasible without reducing the acreage under other important high value crops. If acreage is not allowed to scale up to meet the growing demand, consumer price will increase, or export has to be restricted or import has to be resorted, which will entail the loss of foreign exchange. Hence, bridging the yield gap or increasing the yield potential would be the solution in the long-run.

The major reason for the instability of onion after period II was mainly due to Area instability and partly due to yield. Volatility in the market price results in area instability. This may be partly mitigated by providing timely market information prices, upgrading information, storage facility, and extending the weather based crop insurance to the farmers.

\section{References}

1. Kumar B, Mistry NC, Singh B, Gandhi CP (2011) Indian Horticulture Database 2011. National Horticulture Board, Ministry of Agriculture, Government of India. 
Citation: Immanuelraj TK, Dastagiri MB, Sajesh VK (2014) Growth and Instability of Onion Production in Maharashtra, India. J Glob Econ 2: 107. doi:10.4172/2375-4389.1000107

2. Morgan KL (2012) Onion Profile. Agricultural Marketing Resource Centre.

3. Kumar P (1996) Market Prospects for Upland Crops in India. CGPRT Centre, Working Paper Series No. 20.

4. Paroda R S (1999) Towards sustainable agricultural exports - new paradigm. Presidential Address, Fourth Agricultural Science Congress Report, Jaipur, India.

5. NHRDF (2012) Annual progress report, National Horticulture Mission.

6. NHRDF (2012) Vision 2030, National Horticulture Mission.

7. SFAC (2012) Market intelligence system baseline data for potato and onion. Department of Agriculture and co-operation, Ministry of Agriculture, Government of India.

8. Singh IJ (1989) Agriculture instability and farm poverty in India. Indian J Agric Econ 44: 1-16.

9. Tomek WG, Robinson KL (1981) Agricultural product prices. Cornell University Press, Ithaca, New York.
10. Abler DG, Tolley GS, Kripalani GK (1994) Technical change and income distribution in Indian agriculture.

11. Eicher CK, Staatz JM (1998) International Agricultural Development, JHU press, London.

12. Gummagolmath K (2012) Trends in marketing and export of onion in India. Research Report, National Institute of Agricultural Marketing, Jaipur.

13. DES (2012) various years, Agricultural Statistics at a Glance, New Delhi, India

14. Mood AM, Graybill FA, Boes DC (1974) Introduction to the theory of statistics. McGraw-Hill, Tokyo.

15. Granger CWJ (1969) Investigating causal relations by econometric models and cross spectral methods. Econometrica 37: 424-438.

16. http://www.fao.org/docrep/013/i2050e/i2050e.pdf 